\title{
Host response to tuberculosis as basis for rational design of vaccines and biomarkers
}

\author{
Stefan HE Kaufmann \\ From Immunodiagnosis of Tuberculosis: New Questions, New Tools \\ Virginia, VA, USA. 21-23 September 2008
}

The current diagnostic techniques are not effective in key areas of tuberculosis (TB) research, such as predicting susceptibility, treatment outcome, and monitoring the effectiveness of drug or vaccine trials. Hence, more emphasis is to be placed on biomarker research. A biomarker is a characteristic feature that is objectively measured and evaluated as an indicator of a biological or pathological process or a response to therapy or prevention. Peripheral blood cells may not provide an accurate picture of what is happening in a TB patient at the site of disease manifestation, i.e., the granuloma. The fact that granulomas reach a point where they become largely autonomous and the immune response controls itself in the granuloma, has presented challenges. To address this point, our team infected splenectomized lymphotoxin $\beta$-receptor-deficient mice, which have no secondary lymphoid organs, with a small dose of $\mathrm{Myco-}$ bacterium tuberculosis (M.tb). Without lymph nodes and spleen, the mice mounted an immune response and survived. Upon further analysis, CD8 and CD4 T-cells were generated in the granulomas as well as central memory and multifunctional $\mathrm{T}$ cells. Mice were then infected with M.tb, cured with antibiotics and then reinfected. When reinfected mice were compared to mice with a primary infection, we found that protective memory had developed. We conclude that granulomas can develop an immune response in the absence of lymph nodes and spleen. Moreover, in a study of TB lesions in humans, we found that the same appears to occur.

Using metabolomics, and working with the company Metabalon, we examined a combination of metabolites in latently infected individuals and patients with active TB disease to define a profile to differentiate healthy

Correspondence: kaufmann@mpiib-berlin.mpg.de Department of Immunology, Max Planck Institute for Infection Biology, Berlin, 10117, Germany infected from diseased individuals. Diagnoses made by metabolomics profiles were equally accurate as clinical diagnoses. Metabolomics was also used to identify markers for cell exhaustion, which can lead to reinfection. In particular, we studied the metabolite tryptophan, the degradation of which is involved in suppressive mechanisms. These studies were complemented using transcriptomics. Dendritic cells were stimulated with ManLam, a bacterial cell wall lipid component that binds to DCSIGN, a host cell receptor known to be involved in immunosupression. This binding also caused the cells to over-express the enzymes involved in the degradation of tryptophan. We consider this pathway to be involved in reactivation of $\mathrm{TB}$ and sustenance of active disease.

Published: 17 December 2010

doi:10.1186/1753-6561-4-S3-O7

Cite this article as: Kaufmann: Host response to tuberculosis as basis for rational design of vaccines and biomarkers. BMC Proceedings 20104 (Suppl 3):07.

Submit your next manuscript to BioMed Central and take full advantage of:

- Convenient online submission

- Thorough peer review

- No space constraints or color figure charges

- Immediate publication on acceptance

- Inclusion in PubMed, CAS, Scopus and Google Scholar

- Research which is freely available for redistribution 